\title{
1 CORINTHIANS 14:26-40 IN THE THEOLOGICAL RHETORIC OF THE ADMONITION CONTROVERSY
}

\author{
DANIEL F. GRAVES*
}

Trinity College, Toronto

\begin{abstract}
This paper discusses competing notions of the concept of 'order' in the Admonition Controversy with respect to the interpretation of the decorum of 1 Corinthians 14:26-30, a text principally concerned with order in worship. As the controversy ensued the understanding of 'order' broadened to include church discipline and polity, both Puritan and Conformist alike constructed their polemic with a rhetorical appeal to the Pauline text in question-interpretations at odds with each other. Furthermore, both sides understood their interpretation as standing faithfully in the tradition of Calvin. This paper follows the appeals to 1 Corinthians 14:26-40 by Advanced Protestants and Conformists from its use in the treatise 'Of Ceremonies' found in the Book of Common Prayer, through the Admonition to the Parliament, the responses of John Whitgift and Thomas Cartwright, and finally Richard Hooker's Preface to the Lawes of Ecclesiastical Politie.
\end{abstract}

KEY WORDS: Admonition Controversy, John Calvin, John Whitgift, Thomas Cartwright, Richard Hooker, 1 Corinthians

\section{Introduction}

Order was a watchword of the Admonition controversy. In the first instance, for the Puritan and presbyterian, it was first and foremost about the adoption of a godly order of worship that was faithful to Scripture. For the Conformist, on the other hand, it was primarily about following the legally prescribed rites of the English Church. Yet, for each side of the debate, there were deeper levels of meaning, and to some extent, shared meaning. For the Puritans, adherence to the godly order was a thing of beauty in itself and reflective of God's ordering (and reordering!) of the world. Adherence to godly order in worship, as laid out in Holy Scripture, was a sign of God cutting through the morass of disorder and chaos that was 'Romish superstition'. Adherence to godly order led to peace. The Conformists, equally suspicious of 'Romish superstition' and Puritan innovation, defended the liturgy of the Elizabethan Settlement, namely Cranmer's slightly revised second Prayer Book, out of a desire to maintain order both in Church and society. They, too, felt

* The Reverend DANIEL F. GRAVES (MDiv 2007, University of Trinity College, Toronto) is a priest in the Anglican Diocese of Toronto and a graduate student at Trinity College, Toronto. Email: fr.daniel.graves@gmail.com. 
that order was reflective of God's peace, but to them that order was of a more expansive magnitude. Of course, this underscores the very different and conflicting concepts of 'church' and what that term encompassed for each party. For the Puritans and presbyterians, Church and civil society were not the same thing. For the Conformists there was little distinction; Christian society was the Church. This led to the charge that the Puritans were nothing more than seditious separatists, seeking to upset the order of the Christian commonwealth. The Puritans charged the Conformists with an unwillingness to fully embrace Reformation principles and as continuing to embrace forms, rituals, and governance that were clearly antiChristian. Both strove fervently for an order of service that was reflective of God's peace, and both were convinced that peace was the evidence of God's favour upon both their forms of service and their ecclesiastical polity.

Central to this controversy was how Scripture, and in particular the concept of 'order' enumerated by Paul the apostle in 1 Corinthians 14:26-40, was rhetorically marshalled in the competing polemic to defend each position. It is of particular interest that both sides took recourse and found support in the same words of the Apostle. It is the purpose of this paper to investigate how 1 Corinthians 14:26-40 (and in particular verse 33, 'for God is not a God of confusion but of peace'; and verse 40 , 'but all things should be done decently and in order') functions rhetorically in the religious polemic of each side of the Admonition Controversy. As each side looked to Calvin for support, I will examine briefly how Calvin employed these texts with respect to his own context, which, to my mind, is what in part establishes them as part of rhetorical 'tool kit' that subsequent controversialists access. We then turn to the Admonition Controversy itself and examine the use of 1 Corinthians 14:26-40 in The Admonition to the Parliament, subsequently examining Whitgift and Cartwright's responses in turn. Finally, we turn to Richard Hooker, with a special focus on the Preface to the Lawes of Ecclesiastical Politie and briefly examine how he engages with this locus of Scriptural material. The result will be to underscore how both sides in approach this material with a common hermeneutical purpose which yet plays out in opposing readings that are employed against each other rhetorically within the polemic of the debate.

\section{Calvin's Use of 1 Corinthians 14:26-40}

1 Corinthians 14:26-40 was a text that was crucial for Calvin in his interpretation of order. It is impossible in the scope of this paper to conduct a thorough review of Calvin's reading and application of this text, so our own review is limited to three observations.

The first observation is derived from the Prefatory Address to Francis I in the Institutes of Christian Religion, in which Calvin seeks to distance himself from the sedition of more radical reformers, with which he is accused of being aligned, instead asserting himself and his own theological program as being of a peaceable order:

PERICHORESIS 12.1 (2014) 
But I return to you, O King. May you be not at all moved by those vain accusations with which our adversaries are trying to inspire terror in you: that by this new gospel (for so they call it) men strive and seek only after the opportunity for seditions and impunity for all crimes. 'For our god is not the author of division but of peace [1 Corinthians $14: 33 \mathrm{p}]$... And we are unjustly charged, too, with intentions of such sort that we have never given the least suspicion of them. We are, I suppose, contriving to overthrow the kingdoms-we, from whom not one seditious word was ever heard; we whose life when we lived under you was always acknowledged to be quiet and simple; we who do not cease to pray for the full prosperity of yourself and your kingdom, although we are now fugitives from home! (Calvin, 1960: 30).

In this instance, Calvin has appealed to 1 Corinthians 14:33 to counter a charge that his theology is seditious. This is in sharp distinction to the immediate context of the biblical text itself, which is primarily concerned about order in worship. Of course, for Paul, the decorum of worship is not unrelated to the peaceful ordering of the Church, and Calvin, ever the careful exegete would have being working with this contextual reading of the Pauline text. The important thing to note is the use of this text in defending Calvin's peaceable citizenship. This is an interpretation of the text that will recur as we explore the responses to the Admonition.

The second observation may be gleaned as from IV.10 of the Institutes in which Calvin links church order with civil order:

We see that some form of organization is necessary in all human society to foster the common peace and maintain concord. We further see that in human transactions some procedure is always in effect, which is to be respected in the interests of public decency, and even of humanity itself. This ought especially to be observed in churches, which are best sustained when all things are under a well-ordered constitution, and which without concord become no churches at all. Therefore, if we wish to provide for the safety of the church, we must attend with all diligence to Paul's command that 'all things be done decently and in order [1 Corinthians 14:40]' (Calvin, 1960: 1205).

This makes clear the connection that Calvin was getting at in the Prefatory Address between ecclesiastical order and public order, once again appealing to the particular Pauline text that speaks to order in worship, clearly underscoring an essential cohesion in Calvin's understanding of the concept of 'order.' In this instance, though, he is not generally addressing his theological program, but is more specifically addressing matters of polity.

The third observation has to do with the specifics of ordered worship. To be sure, Calvin is adamant that there are things laid down in Scripture that ought positively to be followed and which have been previously ignored or usurped:

there is danger here lest, on the one hand, false bishops seize from this the pretext to excuse their impious and tyrannous laws, and on the other, lest some be overscrupulous and, warned of the above evils, leave not place whatever for holy laws. Consequently, it behooves me to declare that I approve only those human constitutions which are 
founded upon God's authority drawn from Scripture, and, therefore, wholly divine (Calvin, 1960: 1207).

Calvin finally addresses the specific issue of ordered worship and clearly elucidates the principle of the decorum when he states:

let us take, for example, kneeling when solemn prayers are being said. The question is whether it is a human tradition, which any many may lawfully repudiate or neglect. I say that it is human, as it is also divine. It is of God in so far as it is part of that decorum whose care and observance the apostle has commended to us [1 Corinthians 14:40]. But it is of men in so far as it specifically designates what had in general been suggested rather than explicitly stated (Calvin, 1960: 1207-8).

Ceremonies not positively taught in Scripture are permissible as long as they do not stand in a conflicted relationship with those positively taught. Furthermore, if such human traditions cohere with the Pauline decorum that 'all things be done decently and in order', they may indeed be counted as 'of God'. The decorum is a general principle that may be applied particularly in light of other positive and negative pronouncements in Scripture. This is nuanced reading of the decorum of 1 Corinthians 14:40 which was not always followed so generously by later advanced reformers.

\section{'Of Ceremonies: Why Some Be Abolished and Some Retained' and The Admonition to the Parliament}

The note 'Of Ceremonies: why some be abolished, and some retained', which prefaced the 1549 Prayer Book (and all subsequent editions), set forth the principles for liturgical reform that would undergird the Conformist defense of the Prayer Book throughout the latter part of the sixteenth century. It argued that ceremonies which have their beginnings in man's institution, even with Godly intent, can be turned to vain and superstitious purposes and be abused. Even such godly ceremonies, once profaned, are better set aside than retained. This is possible, because unlike the ceremonial of the Old Testament,

Christ's Gospell is not a Ceremoniall lawe (as much as Moses lawe was) but it is a relygion to serue God, not in bondage of the figure or shadowe: but in the freedome of spirite, beeyinge contente onely wyth those ceremonyes which do serue to a decent ordre and godlye discipline, and such as bee apte to stirre up the dulle mynde of manne, to the remembraunce of his duetie to God, by some notable and speciall significacion, whereby he myght bee edified (Gibson, 1910: 287).

Thus, the criterion for inclusion of a ceremony is that it must serve a 'decent order and godly discipline,' and furthermore, that it must be edifying and 'apte to stirre up the dull mynde of man', encouraging him in his Christian duty. This is the standard by which all ceremonies are to be judged, and thus if they miss the mark 
in this way, they ought to be dispensed with. There is a clear congruency here with the third observation we made with respect to Calvin and the decorum. Similarly, ceremonies devised with such an end in mind ought to be acceptable. In contrast to those who seek the abolition of all ceremonies, this treatise goes on to state, 'wythoute some Ceremonies it is not possible to kepe anye ordre or quyete dyscyplyne in the churche.' (Gibson, 1910: 287) But why is order and quiet discipline such a concern? It is a concern precisely because it is a biblical injunction: 'Let all thynges bee done emong you (sayeth Sainte Paule) in a semely and due ordre', states the treatise, quoting 1 Corinthians 14:40 (Gibson, 1910: 286). As we saw in Calvin's decorum, the same princple rings true here: what Scripture demands is not so much a particular order, but the principle of order. Judging what is orderly and seemly is a matter for the national church. Here, the principle of conveniency is also to be applied, 'For we thinke it conueniente that euery countreye should use such ceremonies, as thei shal thynke beste to the settyng furth of goddes honor, and glorye: and to the reducyng of the people to a moste perfecte and Godly liuig, without errour or supersticion' (Gibson, 1910: 288).

For the purposes of the 1549 Prayer Book, this principle was applied simply to the reform of church ceremonial. Not surprisingly, being a treatise appended to a liturgical book rather than to a treatise on 'church order' questions of polity are absent. It is concerned only for the outward and public manifestation of the Church's worship. Nothing is said, for example, of the retention of an episcopal polity in contrast to a presbyterian polity. It seems that it is the admonitioners who actually move the question forward as to whether the principles in this preface actually apply equally to matters of Church polity (as they appear to have for Calvin). Frere suggests that it is precisely the Puritan failure to make headway with their objections to the minor matters of clerical vesture that leads them to their two-pronged attack on the hierarchy and polity of the Church:

Thenceforward the Prayerbook and the episcopal government of the Church are the central points of the puritan attack: the Genevan Service book and the Presbyterian organization are pushed everywhere forward in direct rivalry to them (Frere, 1907: xiv).

As we shall see, the Puritans draw a link between both ceremony and polity, as Calvin does, and the Conformists readily take up their defense in a similar vein.

If the treatise 'Of Ceremonies' had clearly set forth the principle that the Church had the authority to revise its ceremonies according to the Pauline decorum of order and decency in worship, then the admonitioners attacked the lack of order and decency (as they saw it) in the Prayer Book:

In all their order of service there is no edification according to the rule of the Apostle, but confusion, they tosse the Psalmes in most places like tennice balls. The people some standing, some walking, some talking, some reading, some praying by themselves, attend not the minister (Frere, 1907: 29). 
They refused to submit to Prayer Book usage because considered it a flawed book, as illustrated by that now immortal description 'culled \& picked out of that popishe dunghill, the Masse booke full of all abominations' (Frere, 1907: 21). For the admonitioners, though, ordered worship can only be attained through strict adherence to Scriptural norms and not through extra-biblical judgement. The ceremonial and polity they attack in the Admonition (especially in the section 'A view of Popishe Abuses') are seen as contrary to the express commandments of Scripture, and thus the admonitioners understand themselves as standing in the tradition of Calvin, that is, qualifying the decorum. They were scandalized that liturgy of the Church of England contained many things that are not found in Scripture.

The admonitioners were not opposed to using a book, though. It was not the use of a prayer book, per se, to which they objected. They were quite willing to submit to a single, approved usage, as long as it followed a minimalist godly order which followed Scriptural norms and added nothing non-Scriptural thereto, 'we have at all times borne with that, which we could not amend in this booke, and have used the same in oure ministerie, so farre forth as we might' (Frere, 1907: 21).

While the Admonition recognized that the church purported to ceremonies of good order under the apostolic decorum, in practice what occurred was something far short of the ideal. In particular the use of vestments like the cope and surplice were particularly scandalous:

And as for the apparell, though we have ben long borne in hande, and yet are, that is for order and decencie commanded, yet we know and have proved that there is neither order, nor cumliness, nor obedience in using it. There is no order in it but confusion: No cumliness, but deformitie: No obedience, but disobedience, both against God and the prince (Frere, 1907: 35).

'No order but confusion' is surely an allusion to 1 Corinthians 14:33, 'God is not author of confusion but of peace'. What the Conformists see as decent order is manifestly indecent and deformed according to the admonitioners' standards. They cannot fathom how something can be decently commanded when it is not found in, or indeed, contradicts Scripture. There is no decency in such an order as to embrace such things is a mark of disobedience to God, and interestingly enough, against the prince as well. Here we see a hint that disordered worship is seditious, but the principle is only hinted at and not fully explicated at this point, as we shall later find in Hooker.

The Admonition and the treatise 'Of ceremonies' are of one mind that the Pauline prescription for order is the central liturgical test of faithfulness. Where they differ is in what constitutes 'order', and where the authority rests in determining order. For the Conformist, order flows from properly constituted civil and ecclesiastical authority, which has the wisdom to determine what is liturgically relevant and edifying in the context of the present national Church. The admoni-

PERICHORESIS 12.1 (2014) 
tioners recognize that something has gone completely askew and that the authority of Scripture is being subverted, noting 'Therefore can no authoritie by the word of God, with any pretensce of order and obedience command them, nor make them in any wyse tolerable, but by circumstances, they are wicked, \& against the word of God' (Frere, 1907: 36). For the admonitioners (and other advanced English protestant that we might conveniently name Puritans) Scripture was the supreme authority under which all were subject. For this reason they refused to sign the Articles or submit to earthly authority, even if such authority was considered divinely appointed. The admonitioners desired one simple thing-a godly order of worship. In their estimation, the Prayer Book failed to meet Calvin's qualification of the Pauline decorum, as in places they perceived it to be distinctly non-Scriptural. The Genevan order was an alternative considered much more faithful on all counts.

While a fundamental agreement existed in the importance of the Pauline imperative of 1 Corinthians 14:26-40, a major disagreement ensued over what that actually meant and where the interpretive authority rested. This is where the chasm widens between the competing readings of the Pauline text and where the distance in interpretive authority leads to the question of order in a broader sense. Disorder in worship is but a sign of disorder on a much more substantial stage, the stage of the commonwealth. As we have seen, the connection between these two understandings of order was drawn by Calvin and in the English context it does not take long for disorder in worship to become the perceived catalyst for both a disordered ecclesiastical polity and a disordered society. While it is true that the Admonition attacks the established polity, its 'archbishops, bishops, chancellors. \&c.,' and its confusion of orders (the deacon and the priest), the Admonition itself does not marshal 1 Corinthians 14:26-40 to its attack on a disordered polity; rather, that text is reserved at this point at least, for its attack on disordered worship, and thus functions in the same limited interpretive landscape as 'Of Ceremonies,' even if the hermeneutic conclusions of each are entirely at odds. What is important for our purposes is that in the rhetoric of the debate over those larger issues of polity, it is precisely the same Pauline locus that becomes the Scriptural evidence that is marshalled by both sides in defense and opposition to each other. It is to the ensuing defense and responses to the Admonition and how they make the common appeal to Paul that we now turn.

\section{Whitgift's Answere, Cartwright's Reply, Whitgift's Defense, and Cartwright's Second Reply}

The Admonition was barely off the press when John Whitgift wrote his substantial An Answere to a certen Libel intituled, An Admonition to the Parliament in 1572. Indeed, even as the Admontion had been supressed, Whitgift essentially reprinted its entirety in his own text in order to respond point-by-point to the Admonition's complaints, thus making the Admonition available to an even wider audience! The 
opening lines of Whitgift's Answere not only sets the tone for rest of the debate, but also makes an important interpretive shift with respect to 1 Corinthians 14:26-40.

Whitgift begins with the rhetorical position that he was almost dissuaded from the task of writing this response, but felt pressed into it nonetheless. He opines that he hates contention (one who simply peruses his voluminous response might be forgiven for thinking otherwise) and makes this assertion on appeal to 1 Corinthians 14:33, noting that 'God is not the author of contention or confusion but of peace' (Whitgift, 1572: first unnumbered page). The importance of this assertion cannot be overstated. The rhetorical piety is obvious, but there is claim happening as well, namely, a political claim rooted in the text of Scripture. Contention and confusion are contrary to God's will, and while the discussion will turn to ordered worship in due course, this is about disorder in our common life, and as we shall see, the commonwealth. Whitgift, like Calvin, appeals to a text about worship to make a political statement. In writing to the Parliament, the admonitioners had placed the whole matter in the civic sphere. Rhetorically, Whitgift claims that he only rises to the task of combatting the admonitioners because the cause of peace so important and so sacrosanct that it must be defended. It is a Scriptural imperative.

Whitgift argues strenuously against the notion that simply because something is not prescribed by Scripture that it cannot be included as an edifying part of the Church's ceremonial. In particular in the questions of where services may be held, of standing, sitting or kneeling to receive communion, of baptizing in a font or in a river, Whitgift reasserts the principle from 'On Ceremonies' that not only are such thing not prescribed but that 'no man (as I suppose) is so simple to thinke that the Church hathe no authoritie to take order in these matters' (Whitgift, 1572: 32). Whitgift had already made the crucial appeal to 1 Corinthians 14:40, 'lette all things be doone decently and in order' (Whitgift, 1572: 22) and asks, 'Dothe he not there giue unto them authoritie to make orders in the Churche, so that all thynges be done in order and decently?' So, not only do we hear in Whitgift an echo of 'On Ceremonies', we also hear echoes of Calvin's decorum. And indeed, as the Answere progresses we find that Calvin is very much on Whitgift's mind. In response The Admonition's criticism of liturgical custom and tradition that is maintained in the Church, Whitgift offers a lengthy quotation from the Institutes (Whitgift, 1572: 25-28) and makes the following conclusion:

That in Ceremonies and externall discipline, hee that not in Scripture particularly determined any thyng, but lefte the same to hys Churche, to make or abrogate, to alter or continue, to adde or take awaye, as shall be thoughte from tyme to tyme moste convenient for the present state of the Church, so that nothing be done againste that general rule of Saincte Paule 1 Corinthians 14 Let all things be doone decently and in order (Whitgift, 1572: 28).

PERICHORESIS 12.1 (2014) 
In this clear reiteration and restatement of the assertion found in 'Of Ceremonies,' with strong support from the preceding lengthy quotation from Calvin's Institutes, Whitgift asserts that not only is the fight over order a contention about correctly interpreting Scripture, but a contention over correctly interpreting Calvin. We shall see this time and again, with a culmination in the third chapter of the Preface to Hooker's Lawes. There is one detail, though, that distinguishes Whitgift's restatement of the principle from 'On Ceremonies', namely the addition of 'and externall discipline' to what the Church has authority to regulate. Of course, this is a principle that is further defined in Article XX of the Articles of Religion. Not only ceremonies, but also 'externals' are subject to the wisdom of the Church under the exigencies of local circumstance. Thus, conveniency emerges as a major hermeneutic lens for the Conformist case. Whitgift had previously asserted (following both Calvin and the Articles of Religion) that Scripture contains all things necessary to salvation (Whitgift, 1572: 28), but he now makes clear what does not fall under that category, namely ceremony and externals. 'Externals' is a broad category and Whitgift eventually goes on to state what was quickly becoming the conformist norm:

For in suche matters not commanded or prohibited in Scripture touching ceremonies, discipline, and gournement, the Churche hath authoritie from tyme to tyme to appoynte that which is moste conuenient for the present state as I have before declared (Whitgift, 1572: 44).

Significantly, 'externals' are now defined as 'ceremonies, disciplines and gouernement,' thus elaborating clearly and distinctly what falls under the rubric of what should 'be done decently and in good order' by the Church under the Pauline decorum of 1 Corinthians 14:26-40. The not-so-subtle hermeneutic play here is that the Pauline decorum now applies both to ceremony and to other externals, an advance beyond the earlier 'Of Ceremonies' but one that appears justified by analogy, through the consolidation of what pertains to salvation in the Articles of Religion and through direct appeal to the Pauline decorum as articulated by Calvin. Whitgift seeks to establish that his adversaries go beyond Calvin and he himself claims Calvin as his own authority.

It is clear that both sides appeal to the Pauline decorum, and as outlined earlier, the question is where does the authority for such order come from? For Whitgift, in true Conformist fashion, it is in the hands of the magistrate (Whitgift, 1572: 45). To rail against such authority is contrary to the Elizabethan principle of an ordered commonwealth, which is consequently contrary to will of God. Confusion, Whitgift asserts, 'is the seede of contention and brawling' (1572: 2). In his estimation, if his adversaries carefully considered the writings of Calvin, they would see how wrong-headed their assertions have been, 'These things (among others) I thought good to note out of master Caluines words, which if they were diligently considered such contentions might soone be ended' (Whitgift, 1572: 29). Ulti- 
mately, he concludes that anarchy and Anabaptism are the results of the new discipline (Whitgift, 1572: 86-8). The rhetorical appeal here is to address the admonitioners as if they had been led astray by radicals. He writes confidently that since he has now addressed their concerns and unmasked the errors of their reasoning, exegesis, and arguments, they will 'now fully understand.' He then appeals to them noting that schism and disorder will break loose if the discipline is adopted and then sets up a series result clauses: if you like... and hate / then you will not...; if you do not want these things / then do not embrace the new discipline; if you like learning / then despise...' (Whitgift, 172: 87-8). If his adversaries are not fully persuaded, then the rhetoric is surely directed toward the sympathetic but perhaps fickle reader who might be tempted to the admonitioners' position without Whitgift's own careful guidance to the contrary. Most importantly, though, a full-blown understanding of the Pauline principle of order and decency must, in Whitgift's mind, expansively include both ceremonial order and other externals such as polity, discipline and civic order.

But what makes Whitgift's reading of 1 Corinthians 14:26-40 any more viable than that of his adversaries? We seem to be at an impasse in which two parties use the same text to arrive at vastly different understandings of what 'order' looks like. The answer lies in Whitgift's wholesale condemnation of admonitioners' use of Scripture. He regularly accuses his adversaries of not knowing how to competently use Scripture to argue a case. He rails at them for loading the margins of their tract with references to Scripture that have little or nothing to do with the point they are arguing (see for example Whitgift, 1572: 32, and finally in exasperation 1572: 77: 'Surelie you that thought that no man wold ever have taken paines to examine your margent'). In contrast, Whitgift claims that he stands confidently in a tradition of interpretation that is consistent and coherent. Whitgift has a great mastery of Patristic sources and regularly appeals to them to assist him in interpretation. Furthermore, he regularly appeals to the Puritan's own great ally, Calvin, especially in the case of interpreting 1 Corinthians 14:26-40.

Following Whitgift's Answere, Thomas Cartwright took up the defense of the Admontion by responding to Whitgift's Answere with A Replye to an Answere Made of M. Doctor Whitegifte Againste the Admonition to the Parliament, 1573 (Whitgift, 1851), commonly known as the 'First Reply'. In response to Whitgift's assertion with respect to the Admonition that 'no ceremony, order, discipline, or kind of government may be in the church, except the same be expressed in the word of God, is a great absurdity, and breedeth many incoveniences' (Whitgift, 1851: 190), Cartwright rejoined with 'I say that the word of God containeth the direction of all things pertaining to the church, yea, of whatsoever things can fall into any part of a man's life' (Whitgift, 1851: 190). Cartwright argues this position from several texts, including Proverbs 2:9, 1 Corinthians 10:31, 1 Timothy 4:5, but especially from Romans 14:23: 'Whatsoever is not of faith is sin' to which he adds, 'but faith is not faith but in respect of the word of God; therefore whatsoever is not done by 
the word of God is sin' (Whitgift, 1851: 190). As Whitgift had rejected this exclusivist approach in the Admonition, he likewise rejects Cartwright's formulation. In asserting that Scripture contains 'all things necessary to Salvation', he does not deny that Scripture also contains generally a direction for ordering the Church and men's lives, but he refuses to accept the Puritan position that 'the Scriptures do express particularly everything that is to be done in the church,' and as his usual custom, he attacks Cartwright's conclusions through an attack on his exegesis (Whitgift, 1851: 191), demonstrating that the Puritan cause is based on a sloppy and indiscriminate reading of their cited texts.

Cartwright, though, does not see his appeal to Scripture as sloppy or indiscriminate. In fact, he attempts to make a systematic argument by offering what Horton Davies (1996: 51-2) has called the 'four infallible Pauline tests'. In appealing to four key Pauline texts, Cartwright attempts to make an argument for the Puritan version of order using texts that on face value speak to the Conformist version of order. By this, it is meant that the texts in question are general, rather than particular. This should come as no surprise, for as we have seen, they would be texts from which Calvin also argued the decorum, which is an argument from the 'general' rather than the 'particular'. Cartwright's four principles are as follows:

1. 1 Corinthians 10:32-The first, that they offend, not any, especially the Church of God.

2. 1 Corinthians 14:40-The second is (that which you cite also out of Paul), that all be done in order and comeliness.

3. 1 Corinthians 14:26-The third, that all be done to edifying.

4. Romans 14:6, 7-The last, that they be done to the glory of God (Whitgift, 1851: 195).

Cartwright, in principle, is in agreement with the Conformist case, underscoring to my mind at least, a fundamental shared theological Calvinist framework. But Cartwright goes on to attack Whitgift (as the admonitioners had, previously) for his defense of matters of order that seem contrary to matters clearly ordered by Scripture, for example, the creation of non-Scriptural offices such as that of Archbishop, or the abrogation of the role of the elder, the confusion of the role of the deacon, and the appointing of shepherds without flocks (Whitgift, 1851:196).

It seems, therefore, that both the Puritans and the Conformists shared a 'baseline' understanding of the principle of order from generality. What was in question was just how much flexibility was allowed in the particularities; which things were truly 'matters indifferent'? Whitgift had a much more liberal understanding of the principle of 'general order' that allowed the English Church much more flexibility in ordering its life, whereas Cartwright saw the general principle as one that was to be very conservatively applied, only in the cases in which there was no 
clear, positive Scriptural prescription. In many cases the Puritans saw 'clear Scriptural prescriptions' where such prescriptions might have appeared much more ambiguous to the Conformist. This is the sort of thing that Whitgift was attacking when the Puritan scriptural citations seemed only vaguely to apply (if at all!) to the matter being argued. Indeed, Whitgift goes on to attack Cartwright's rules (Whitgift, 1851: 197). With respect the first rule, he accuses Cartwright of sleight of hand by inserting the word 'especially' into the text, thus twisting the text to make it meet his own preconceived program. With respect to the second rule, Whitgift wholeheartedly concurs with Cartwright, but begs the question of who is to judge what is well-ordered, those in proper authority or the private man? More on this problem, below. With respect to the third rule, Whitgift attacks Cartwright's the use of 1 Corinthians 14:26 of extrapolating a general principle from a particular example. Whitgift reminds Cartwright that Paul is not speaking in this case about all ceremonies, but in this context a particular set of disruptions to worship in the Corinthian church, and that it is wrong to create a general principle out of this sort of particularity. The fourth rule we shall pass over as it does not concern our argument. In all of this, Whitgift proves himself the more careful exegete. Even though Whitgift might easily find himself in agreement with the concept of general principles shaping the decorum, he objects to Cartwright's sloppy exegesis in arriving at the principle.

Questions of both adiaphora and conveniency assert themselves into the foreground. Ironically enough, the rules that Cartwright articulates are precisely the tools by which the conveniency of an order, change, or retention of order or custom are to be evaluated as a matter of first course for a Conformist. And yet, in spite of putting these rules forward, for Cartwright, like the admonitioners, it works the other way around. If, and only if, there is no prescription in Scripture, then, and only then, should the four rules apply. Conveniency is not of first importance for the Puritan, as it is for the Conformist. Cartwright desires to see all things tested against the four rules, regardless of conveniency (Whitgift, 1851: 195). The difference is subtle, but significant. Whitgift can accuse Cartwright of not differing from him because they agree on the rules. Yet, where they disagree it is with respect to their application. For Cartwright, 1 Corinthians 14, in particular, is prescriptive against making changes to church order as outlined in Scripture. For Whitgift, the decorum is permissive.

Ultimately, Whitgift brings the argument around to the issue of authority, where it must ultimately always find its insurmountable summit. Whitgift makes the case that it is those who have the care of the Church have the authority to define what is comeliness and order (Whitgift, 1851: 197); it is not given over to private men's opinions. The matter of determining conveniency is in the hands of those lawfully appointed. Whitgift argues, for example, that Scripture sets out no appointed hours for worship, and yet, it is in the purview of the authority of Church, not of private men, to set out such a rule (Whitgift, 1851: 199). Whitgift 
finally suggests that the point of their disagreement is in whether or not the English Church has lawfully used her authority (Whitgift, 1851: 200). This gets to the heart of the conflict: where does authority rest? The question must remain unresolved and beyond the scope of this paper, but what is clear is that while both camps understand Scripture as authoritative, they disagree over where exegetical authority rests. Whitgift assumes that such authority if found in the lawful structures of the Church in commonwealth, which if not divinely appointed are divinely approved. 'Private opinion' is to be eschewed at all costs. But is the Puritan interpretation simply 'private opinion' or an emerging consensus of interpretation? Again these questions are larger than this paper, but the appeal to text such as 1 Corinthians 14:26-40 as part of the ongoing rhetoric and polemic serve to underline the widening chasm between Conformist and Puritan interpretations and use of Scripture.

Cartwright chose not to let the matter rest and responded with his The Second Replie of Thomas Cartwright: against Mister Doctor Whitgiftes Second Answer touching the Church Discipline, 1575 (published in two parts), a work so voluminous that it has never received a complete modern edition. With respect to the polemical and rhetorical use of 1 Corinthians 14 (and the other texts that began to be marshalled in the controversy over Church order), Cartwright attacked Whitgift's defense pointby-point. We shall not deal with Cartwright's response to all of Whitgift's critique of the four rules, but only with the ones that pertain to 1 Corinthians 14:26-40. As will be recalled, Whitgift argued that the issue in 1 Corinthians 14:26 was not a general rule about Church order, but rather, a particular response of the Apostle to the particular issue of disordered worship (tongues, prophecies, and so forth). Whitgift castigated Cartwright for using Paul to argue a general rule from a particular example. We took that as a case of Whitgift unmasking a piece of unskilled and sloppy exegesis. However, Cartwright shows that he has a deeper understanding of Pauline rhetoric and argumentation than Whitgift would allow. In the 'Second Reply' Cartwright suggests that it is in the nature of Pauline argumentation to draw general examples from particular cases:

To the thirde rule / that all shoulde be doone unto edifying: he saithe that yt can not be applied to all things generally vsed in the churche, but to praiers, tounges, \&c. specified in that chapter, as if it were not the ordinary of the Apostell / to proue the particulars / by the general / and so to conclude / that the exercises off praing / singing \&c. shoulde be doone to edifying because all things muste be doone (Cartwright, 1575: LXIII.30$37)$.

Therefore, in Cartwright's estimation, it is perfectly legitimate to argue the general from the particular, contra Whitgift, for it is the method adopted by the Apostle, himself. Because this is the case, the particular case of the Corinthians' problems must, per force, serve as the basis upon which a general rule is articulated. 
Whitgift had also argued that Cartwright had consistently confused the concepts of the public and the private. Cartwright, in responding to Whitgift's critique of his first rule (1 Corinthians 10), argued that a general rule must apply both publically and privately, as it made no sense that 'the Lorde were so carefull in private offences / and careles in publike' (Cartwright, 1575: LXII.2-3). With respect to the third rule (1 Corinthians 14:26), when Cartwright establishes the Pauline principle of proving the general from the particular, he extends that to argue for the public from the private as well:

... yt is manifeste that the Apostell / carrying yt also unto thinges indifferent / will haue this to be the rule / off our priuate actions / myche more off suche publike actions / as I haue before declared (Cartwright, 1575: LXIII.1-4).

Thus, we encounter another fundamental exegetical difference that allows the text to be marshalled rhetorically for diametrically opposed polemical ends. From Cartwright's vantage point, if Whitgift would only look more closely, he would see that the rule is self-evident and given by the Apostle. Returning to the problem of authority once more, Cartwright's authority is not private, but rooted in the text of Scripture; nor is his exegetical method a private one, but rooted in the method of Scripture, itself. For Cartwright (and for the Puritans as a whole) Scripture provides the tools for its interpretation. If one wishes to understand what Paul would think, then one must examine Paul's general method and extrapolate the conclusion from the particular Pauline problem to a general Christian rule. 1 Corinthians 14 (along with other several key texts, especially Romans 14) become the rhetorical ground on which this theological assertion is made.

Given the page count of the controversy so far, we might be grateful that Whitgift made no further reply. Given what we know of his method, should he have chosen to respond, it is likely he would have done so by countering Cartwright with several examples of how Cartwright's method might be taken to absurd extremes, and demonstrated this by examples in which Pauline particulars ought not be taken to their logical general conclusions. He might have also further explored the private-public convergence in Cartwright by demonstrating the dangers to the commonwealth of taking such convergences to their natural conclusion. These are mere speculations, and it can be doubtful that a further response from Whitgift would have offered anything edifying or persuasive in terms of bringing the argument to a conclusion. Further response was left to others. One such response was to come from Richard Hooker.

\section{Richard Hooker: Preface to Of the Lawes of Ecclesiastical Politie}

It might be said that the Admonition Controversy never really came to an end, rather it just fizzled out. After the Whitgift-Cartwright exchange came to a close, more radical streams of Protestantism reared their heads in the Marprelate controversy, the threats of the writings of Henry Barrow, and in the Hackett incident. 
In each of these cases, threats to ecclesiastical peace were deemed threats to the commonwealth and seditious in nature. It might be said that the memory of Peasants' revolt and other forms of radical continental Protestantism never faded. They remained just as vivid a memory in late sixteenth-century England as when Calvin wrote in the Prefatory Address Francis I in the Institutes. In time such memories seem to have formed the substructure of a narrative of never-ending fear of advanced forms of Protestantism. It should be said that this fear was equally buttressed on the other extreme by fears of papistical plots to reclaim England for Rome. Looking back on what we perceive as the monolithic achievement of the Elizabethan Establishment, it can be difficult to truly understand the uneasiness of the late-Elizabethan Conformist, who feared the advanced Protestant on the one hand, and the Papist on the other. This is the world in which Richard Hooker wrote, and of the Establishment he defended.

Whether or not Hooker really believed the Establishment to be under such an ominous threat, as at the precipice of its demise and as something only to be remembered for posterity, as the opening lines of The Lawes of Ecclesiastical Politie suggest or whether that is simply his rhetorical positioning as he opens his treatise is a matter of dispute. What is certain is that there must have been a convergence between that reality and his rhetorical grandiloquence that made it such an engaging opening to his work. To this end, the Preface to the Lawes is both a tightly ordered and emotionally charged thesis statement of the problem before the English Church. For Hooker, the Church is at a crossroads: it can yield to the advances of the Presbyterian movement, and thus open the door to those who desire a more radical and advanced Protestantism or it can hold fast to the Establishment that is faithful to the principles of the Reformation while at the same time exerts a continuity with the best of the Ancient, Patristic, and Medieval Church. In the midst of it all, though, Hooker regards the issue as one of a problem of authority and order. To this extent, he is in continuity with the controversy that has unfolded since the middle of the century.

For Hooker, what is at stake is the problem of order. If the Lawes is about anything, it is about problem of order. Questions of how the Church might order itself are central to its thesis and purpose. Where does the authority to order the Church come from? To whom is such authority designated? And what does such order look like? And of course, which matters are indifferent? These are the problems over which the controversy has raged for nearly half a century, and Hooker addresses them head on by articulating forcefully and clearly that peace is what God desires:

But our hope is that the God of peace shall (notwithstanding mans nature too impatient of contumelious malediction) inable us quietlie and even gladly to suffer all things, for that worke sake which we covet to performe (Hooker, 1977: 1.19-21).

PERICHORESIS 12.1 (2014) 
The reference to 'the God of peace' immediately leads us to suspect a reference to 1 Corinthians 14:33 given the contrast between our human predilection for 'contumelious malediction' and Hooker's goal of quiet suffering, reminding us of the opening of Whitgift's Answere in which he claims himself a lover of peace under the rubric of 1 Corinthians 14:33, that 'God is not the author of confusion but peace'.

In Chapter 3 of the Preface, Hooker now explicitly evokes that text as he accuses his adversaries of leading people astray into their way of thinking. But he does so through a quotation from Gregory of Nazianzus which paraphrases the text: 'For God is not a God of sedition and confusion, but of order and peace' (Hooker, 1977: 14.6-7, italics added). This paraphrase can instructively be compared with the Bishop's Bible and the Geneva Bible which read, 'For God is not the author of confusion, but of peace'. This expansion of the text serves Hooker's purpose to broaden the parallel construction from confusion / peace, to include the additional parallel of sedition / order and equate confusion with sedition, and order with peace. This rhetorical strengthening heightens the polemic against those who would seek to usurp the present established order. This creates an equivalence between civic order and divine peace; and conversely between sedition against the civil authorities with theological confusion. Of course, this is entirely consonant with Hooker's approach to law as outlined in Book I. If all laws emanate from the Second Law Eternal, then the flouting of a civil law is the same as the flouting of a divine law. This is why God is the author of both order and peace, even if it is extrapolated from, and indeed is an interpolation of, the biblical text.

To some extent, this is nothing new. As we have seen, this formal equivalence between confusion and sedition can be found in Calvin, even if he has not used so boldly a manipulated version of the text of Scripture as Hooker has. We have also seen traces of this kind of thought in Whitgift, but here in Hooker the formal equivalence is stated more clearly than ever: sedition is contrary to the law of God.

Hooker further appeals to 1 Corinthians 14:33 in chapter 6 of the Preface (this time in its 'purer' form) when he argues that in matters of contention, a definitive sentence of the magistrate should be sought (on analogy to the Apostolic council of Acts 15) when he writes:

Yet in this case God did not allowe them [the Jews] to doe that which in their private judgement it seemed, yea and perhaps truly seemed that the lawe did disallow. For God is not the author of confusion but of peace, then can he not be the author of our refusal, but of our contentment, to stand under some definitive sentence, without which almost impossible it is that eyther we should avoid confusion, or ever hope to attaine peace. To small purpose had the Councell of Jerusalem bene assembled, if once their determination being set downe, men might afterwards have defende their former opinions (Hooker, 1977: 31.30-32.4).

PERICHORESIS 12.1 (2014) 
And what is peace and how is it attained? Hooker here addresses that old problem of private opinion / public sentence. Where Cartwright would have noted that God did not have two separate rules for the public and private, Hooker recognizes, in the tradition of Whitgift that the two are often at odds. The only way that contentious matters can be settled is by following the example of the apostles and appeal to authority. This closes the argument, eliminates private opinion and attains to peace. Those who continue to put forward their private interpretations not only fail to understand what Scripture teaches but themselves become a threat to the thing Scripture commends the Christian to aspire to, namely order and peace.

Whether or not the eighth chapter of the Preface ought to be considered hastily added or part of Hooker's original plan, its understanding of order is consistent with the earlier part of the Preace. The eighth chapter is a litany of the apocalyptic destruction of all that is held near and dear in the commonwealth. Private opinion becomes the thing that drives the 'foe of order' on like a thorn in the flesh, except this is not the thorn that moved Paul to mission, but rather an unholy, seditious thorn:

For my purpose herein is to show that when the minds of men are once erroneously perswaded that it is the will of God to have those things done which they phancie, their opinions are as thornes in their sides never suffering them to take rest till they have brought their speculations into practise... (Hooker, 1977: 49.2-6).

Hooker concludes the Preface, though, with a plea for peace, order, and unity, that he might be joined by his adversaries in "bands of indissoluble love and amitie, to live as if our persons being manie our souls were but one, rather then in such dismembered sort...' (Hooker, 1977: 52.14-16). Rhetorically, the fear of disorder through sedition is answered by the restoration of order and peace. He hopes that his moderate adversaries will choose peace over the destructive path of radical Protestantism. He evokes the reunification of Joseph and his brothers as the ideal outcome (Hooker, 1977: 53.9-11) and finally makes an appeal (as he began the Preface) to the 'God of Peace' (Hooker, 1977: 53.14).

For Richard Hooker, private opinion was of no account, and was indeed dangerous. The common good was the good above all other to be aspired to and attained, for this good was reflective of the very nature and character of God. A polity which left each man to advance his own ecclesiological fancies could only lead to the destruction of an ordered society, and an ordered society was reflective of God's order. 1 Corinthians 14:33 served the purpose (even if Hooker had to appeal to a glossed version of it) of distinctly linking God's peace with civic order and theological confusion with sedition. 1 Corinthians 14:33 became the rhetorical hammer to be used to beat back his opponents once and for all, to unmask them and identify them for the destructive agents they were, and yet also invite them 
back into the holiness of a godly peace, if only they would turn from their wickedness and live.

\section{Conclusion}

In conclusion, 1 Corinthians 14:26-40 was a 'go to' text for both sides of the Admonition Controversy. An early appeal to the Pauline decorum in this text was logically made in the treatise 'Of Ceremonies' in which exigency and conveniency are principles that govern its application. Not surprisingly, the Admonitioners objected to the hermeneutic principle put into play by 'Of Ceremonies' (and further 'canonized' in the Articles of Religion), whereas the Conformists ran with it. As the controversy unfolded the concept of 'order' and the application of the decorum stretched to include both ceremony and polity, by both the Puritans and the Conformists. Calvin had already established that this text might apply in both circumstances. In the context of the Admonition Controversy we see the Admonitioners and Cartwright placing emphasis on the prohibitive nature of the decorum and arguing for ceremony and polity as only prescribed by Scripture, whereas Whitgift and Hooker place the emphasis on the permissive nature of the decorum. In both cases, each side claimed, with justification, to be following Calvin's interpretation.

It is important to add that in each case, the appeal to Scripture was primary. What varied was how the text was to be interpreted, and where the interpretative authority rested. 1 Corinthians 14:26-40 was a crucial text, marshalled to advance the rhetorical polemic of two conflicting theological and ecclesiological worldviews. The polemic only became more entrenched as the rhetorical appropriation of 1 Corinthians 14:26-40 was advanced by either side.

\section{Bibliography}

***** (1910) Gibson, ECS (ed) The First and Second Prayer Books of Edward VI (Everyman's Library Edition). Exeter: JM Dent \& Sons / Prayer Book Society.

Calvin, J (1960) Institutes of Christian Religion. Louisville, KY: Westminster / John Knox Press.

Cartwright, T (1575) The Second Replie of Thomas Cartwright: against Mister Doctor Whitgiftes Second Answer touching the Church Discipline. Heidelberg: M. Schirat.

Davies, H (1996) Worship and Theology in England: From Cranmer to Hooker, 15341603. Grand Rapids, MI: Eerdmans.

Frere, WH (1907) Puritan Manifestoes: A Study of the Origins of the Puritan Revolt with a reprint of the Admonition to the Parliament and kindred documents. London: SPCK.

Hooker, R (1977) The Laws of Ecclesiastical Polity. In Hill, WS and Edelen, G (eds) The Folger Library Edition of the Works of Richard Hooker, volume 1. Cambridge, MA: Belknap Press of Harvard University Press.

Whitgift, J (1572) An Answere to a certen Libel intituled, An Admonition to the Parliament. London: Henrie Bynnemen for Humfrey Tay. 
Whitgift, J (1851) The Works of John Whitgift, volume 1. Cambridge: Cambridge University Press. 